\title{
The Use of Museum Collection for Studying the Origin of "Rose-Like" Calcite in the Holy Cross Mountains (South-Central Poland)
}

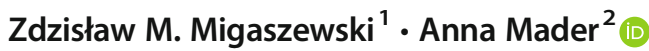

Received: 3 October 2018 / Accepted: 8 May 2019 / Published online: 30 May 2019

(C) The Author(s) 2019

\begin{abstract}
The "rose-like" calcite belongs to the most beautiful decorative carbonate rocks in the Holy Cross Mountains region in south-central Poland. This mineral occurs in the form of veins cutting Devonian limestones. The origin of the rose-like calcite was initially linked to the Variscan orogeny, but more recent studies, conducted in the 1990s of the twentieth century, documented quite a few generations of rose-like calcite mineralization and its Late Permian/Early Triassic age. It is interesting to note that the best example for studying the rose-like calcite provenance in the paleoenvironmental context is polished slabs facing six pillars in the Geological Museum of the Polish National Geological Institute - National Research Institute, Świętokrzyski Branch in Kielce. These calcite slabs come from the abandoned Mt. Zelejowa quarry located near Chęciny. Based on the calcite textural relationships and the results of stable $\mathrm{C}$ and $\mathrm{O}$ isotope determinations (changes in $\delta^{13} \mathrm{C}_{\mathrm{PDB}}$ and $\delta^{18} \mathrm{O}_{\mathrm{PDB}}$ values), the rose-like calcite from Mt. Zelejowa was postulated to be linked to the older and the younger post-Variscan (Permian/Triassic) phases. The $\delta^{18} \mathrm{O}_{\mathrm{PDB}}$ values indicated crystallization temperatures of hydrothermal fluids in the range of $21-59^{\circ} \mathrm{C}$ whereas the index $Z$, based on clumped $\delta^{13} \mathrm{C}_{\mathrm{PDB}}$ and $\delta^{18} \mathrm{O}_{\mathrm{PDB}}$ values $(\geq 120)$, pointed to their marine provenance. No calcite sample showed a significant influence of meteoric waters. The hydrothermal activity took place in a terrestrial environment with developed karstification (hydrothermal paleokarst), which is evidenced by the presence of red-brown internal Fe- and Mn-rich precipitates and single dripstones (stalactites). The polished rose-like calcite slabs are a unique educational example of using stable $\mathrm{C}$ and $\mathrm{O}$ isotopes for discriminating hydrothermal from meteoric karst features. It should be emphasized that these specimens are the only complete collection retained from the current Mt. Zelejowa nature reserve. Both their scientific and educational values raise visitors' awareness of geoheritage and geodiversity protection.
\end{abstract}

Keywords Rose-like calcite $\cdot$ Holy Cross Mts. $\cdot$ Museum collection $\cdot$ Geoheritage $\cdot$ Stable isotopes $\cdot$ Hydrothermal paleokarst

\section{Introduction}

The "rose-like" calcite is one of the most beautiful decorative carbonate rocks (also commonly known as "Holy Cross Marbles") in the Holy Cross Mountains (Góry Świętokrzyskie) region in south-central Poland (Fig. 1). Due

This article is part of the Topical Collection on Geoheritage and Conservation: Modern Approaches and Applications Towards the 2030 Agenda, IX ProGEO Symposium, Poland, 25-28th June, 2018

Anna Mader amad@pgi.gov.pl

1 Geochemistry and the Environment Division, Faculty of Mathematics and Natural Sciences, Jan Kochanowski University, 15G Świętokrzyska St, 25-406 Kielce, Poland

2 Polish Geological Institute - National Research Institute, 21 Zgoda St., 25-953 Kielce, Poland to its white-pink to white-red color as well as unique eyeshaped, banded and brecciated textures, giving a pattern of small red roses or bows, this calcite variety was a valuable and sought-after material by stonemasons during the late Renaissance, Mannerism, and Baroque periods (Wardzyński 2014). The rose-like calcite was mostly used for ornamenting some interior architectural details, including columns, walls, windowsills, stairs, floors, stoups, and candleholders of palaces, churches, and monasteries, or even in some postwar public buildings. Its decorative values were even more deepened by composition with the black Debnik limestone (quarried northwest of Cracow). There are many examples of applications of these two contrasting decorative stones in numerous monuments of the Małopolska province (southern Poland), for example, in the Wawel Royal Cathedral and Our Lady Church in Cracow and Benedictine Abbey in Tyniec near Cracow. Blocks of this mineral were extracted from the late sixteenth century through 1954 in a few quarries located in the proximity of Chęciny, among 


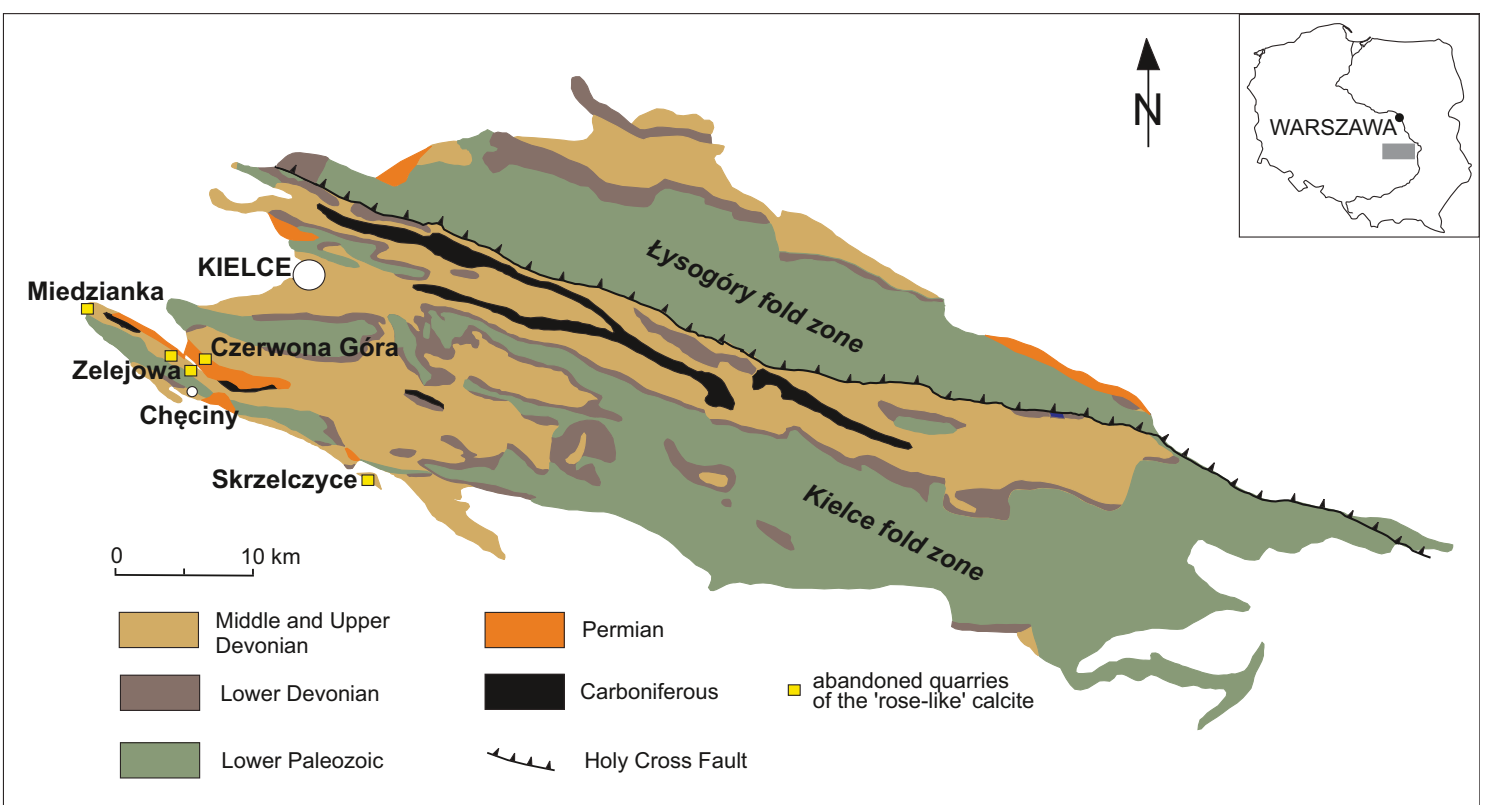

Fig. 1 Location of the largest rose-like calcite quarries against a generalized geologic map of the Holy Cross Mountains (after Filonowicz 1961)

which Mt. Zelejowa (Figs. 2 and 3) was the most famous site (Czarnocki 1932, 1952, 1958; Fijałkowska and Fijałkowski 1973). This is the reason why this calcite is also known by another trade name, "Zelejowa Marble."

When the present building of the Świętokrzyski Branch of the Polish Geological Institute - National Research Institute (PGI-NRI) in Kielce was built in 1960, the pillars of the Museum hall were faced with polished slabs extracted from the Mt. Zelejowa central opencut pit. These decorative and educational slabs make up a part of the PGI-NRI Museum collection. Six of them were cut from a big rough-hewn rose-like calcite block (Fig. 4).

The principal objective of this study was to present scientific and educational values of the rose-like calcite, which is an integral component of the "różanka zelejowska" decorative stone. These unique slabs can be used for studying geologic processes that took place in this part of the region during Late Permian time. To accomplish this purpose, stable carbon and oxygen isotope determinations were performed on 55 microsized samples collected from different textural parts of the rose-like calcite slabs. This enabled us to reconstruct both crystallization temperatures and paleoenvironmental conditions of calcite formation, and additionally provide evidence on overlapped karstic and hydrothermal origin of this decorative stone. These data marked on these polished slabs will enable visitors from the inside and outside scientific community to better understand geologic processes in the context of geoheritage and geodiversity protection.

Fig. 2 View of the Mt. Zelejowa quarry. Photo taken by Czarnocki before 1938 (Król 2007)

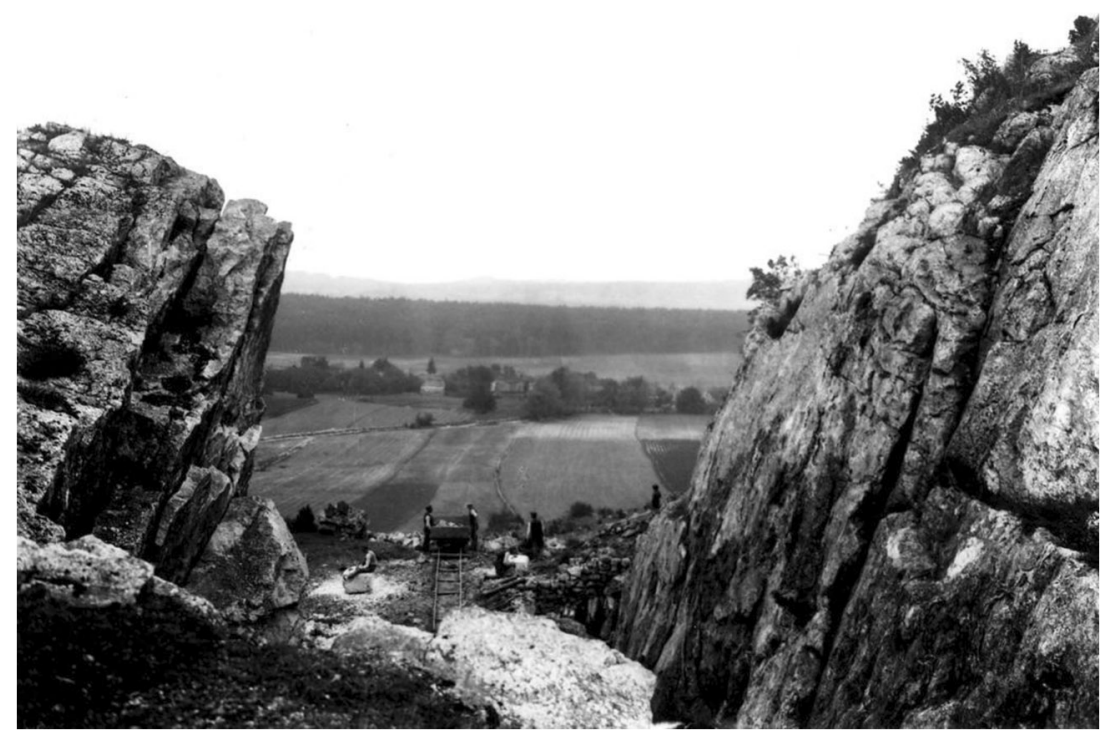




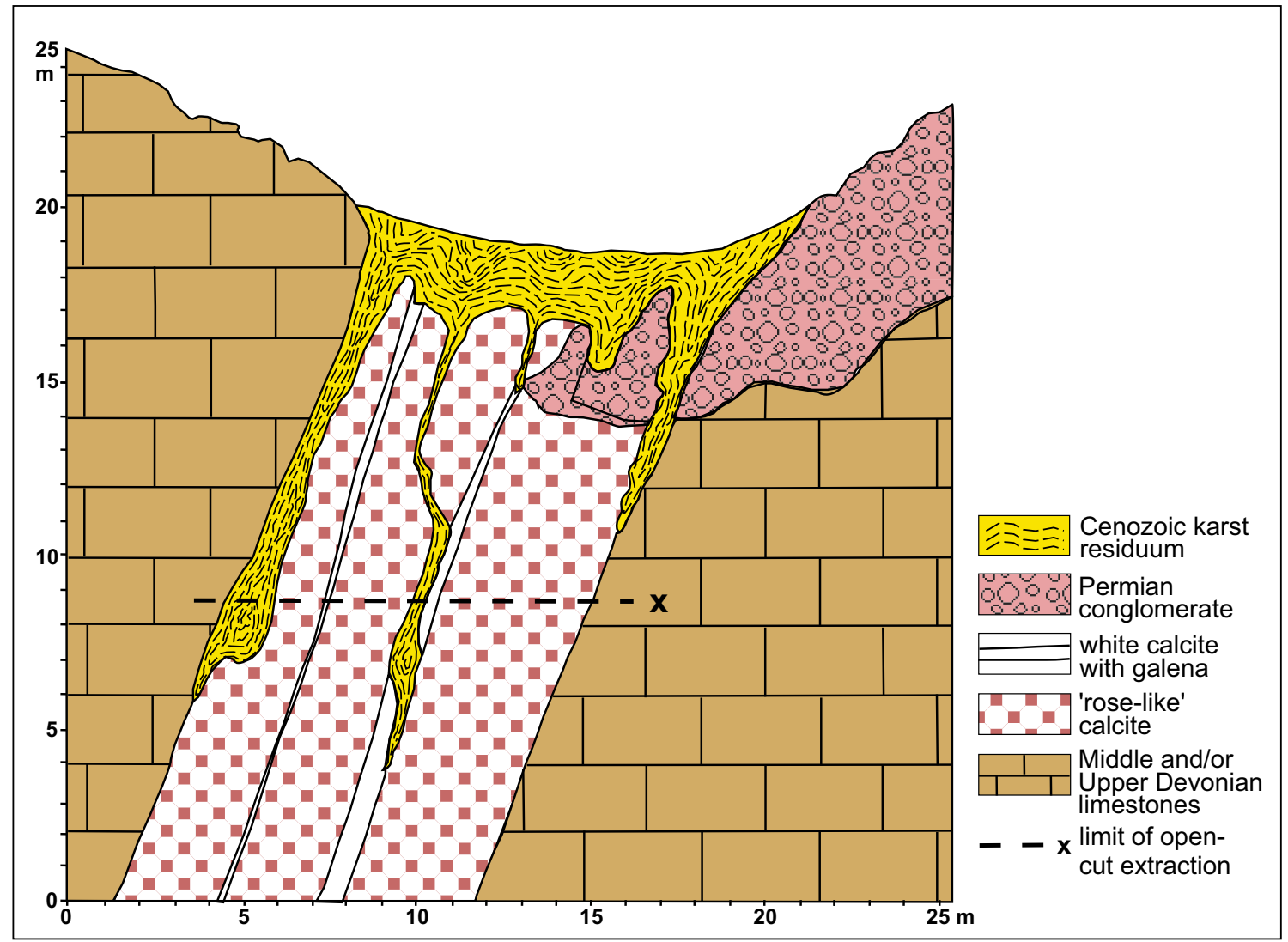

Fig. 3 Schematic section through the brecciated rose-like calcite vein zone in the northern limb of the Chęciny anticline (after Fijałkowska and Fijałkowski 1973, modified)

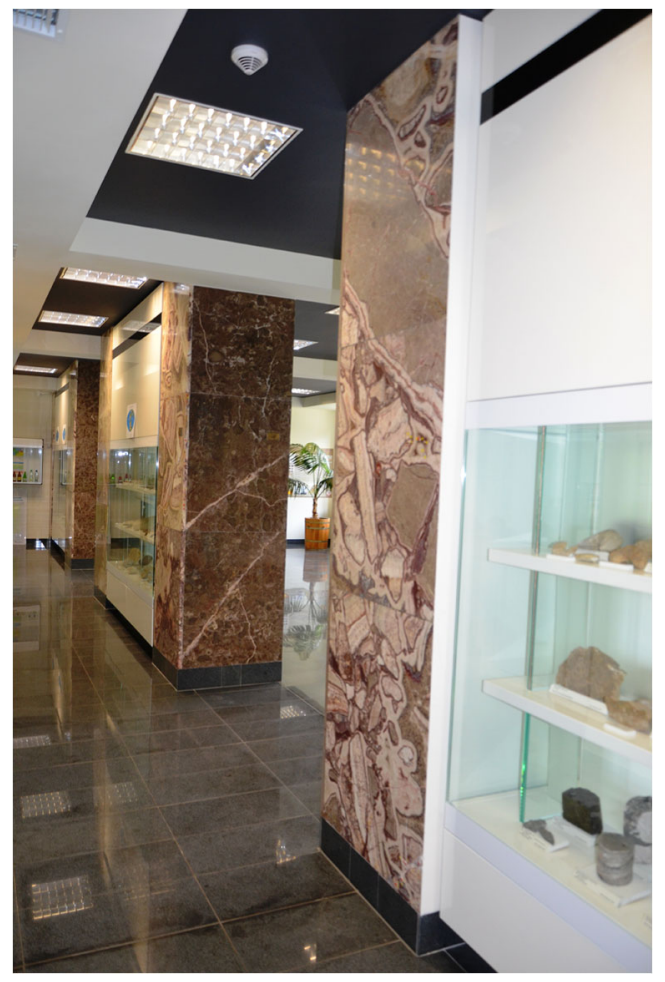

Fig. 4 Pillars faced with the Zelejowa Marble slabs, Museum of the Polish Geological Institute - National Research Institute (PGI-NRI), Holy Cross Branch, Kielce
It is noteworthy that another very illustrative example of a big rough-hewn block of the rose-like calcite can be found near the entrance to the European Centre for Geological Education in the abandoned Rzepka quarry close to Mt. Castle in Chęciny. This block was excavated during construction of the building and was exhibited during the ProGeo Symposium 2018 (Fig. 5).

\section{Geologic Setting}

The rose-like calcite occurs in the southwestern part of the Holy Cross Mountains Paleozoic block (south-central Poland). The area of its occurrence belongs to the Kielce fold zone formed during the Variscan orogeny (Fig. 1). This tectonic unit consists of nearly NW-SE extending anticlines and synclines with the most pronounced Chęciny anticline composed of a Lower Cambrian clastic core and Upper Devonian carbonate wings.

The rose-like calcite occurs mostly within the NNW-SSE to NNE-SSW fault systems cutting Middle and Upper Devonian carbonate rocks. It forms single veins several centimeters thick, or more frequently big brecciated vein zones ranging from several through a dozen meters across, for instance in Skrzelczyce up to $42 \mathrm{~m}$ (Fig. 1). They fill up almost vertical faults $\left(75-85^{\circ}\right)$ within Givetian-Frasnian limestone 
Fig. 5 Rough-hewn block of the rose-like calcite at the entrance to the European Centre for Geological Education in the abandoned Rzepka quarry in Chęciny

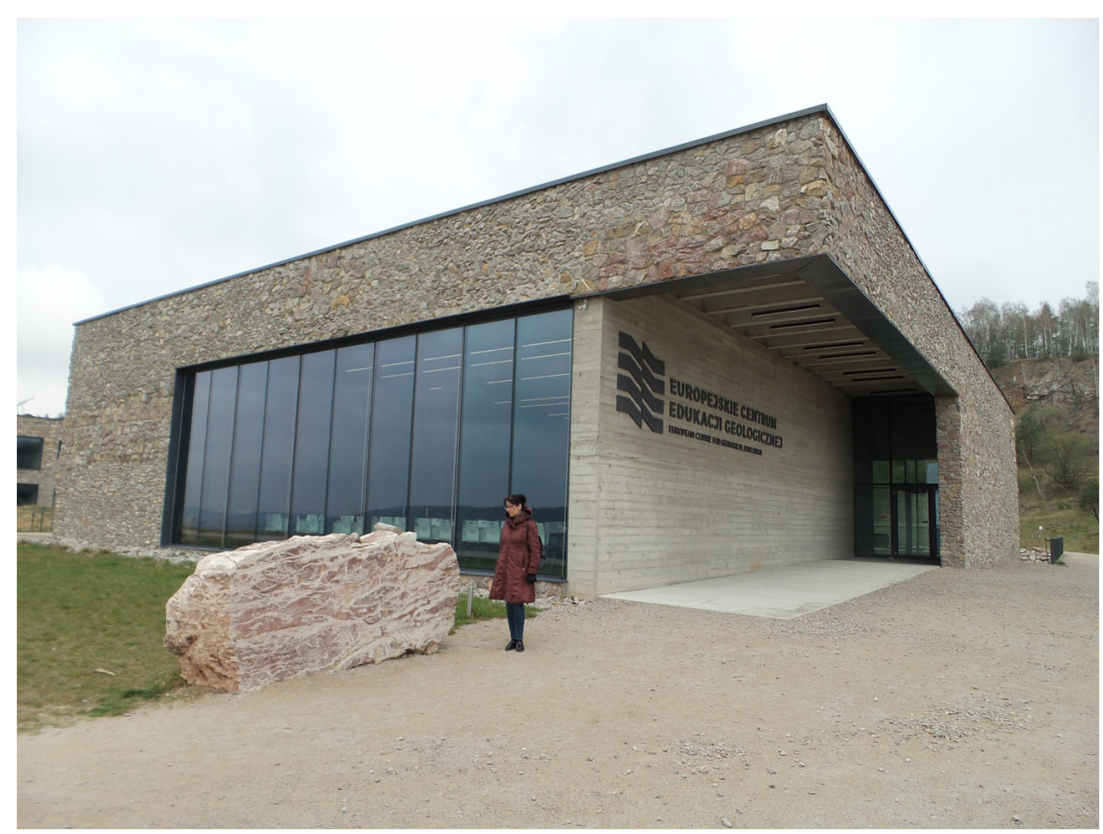

and dolomite formations (Rubinowski 1967, 1971, 1994, 1995; Fig. 3). These zones usually extend at a distance of tens to approx. $500 \mathrm{~m}$. Most of the rose-like calcite veins were identified on the wings of the Checiny anticline. The examined polished slabs come from the abandoned Mt. Zelejowa quarry, which is located in the northern limb of the Checciny anticline.

The origin of the rose-like calcite was initially linked to the Variscan (Mississippian/Pennsylvanian) orogeny (Rubinowski 1967, 1971, 1994). However, the more recent studies indicated the younger age (Late Permianearliest Triassic time, with the main phase in the latest Permian) of the rose-like calcite mineralization in the Holy Cross Mountains (Migaszewski et al. 1996, 1998). This inference was drawn, among others, from the different stable $\mathrm{C}$ and $\mathrm{O}$ isotope signatures and the textural relationships between pebbles and cement-related calcite veins of Lopingian (former Zechstein) conglomerates (Table 2 in Zbroja et al. 1998). These veins do not cut pebbles, thus indicating their formation under sedimentary-early diagenetic conditions. It is interesting to note that the rose-like calcite does not occur within Mesozoic formations of the Holy Cross Mts.

It is worth mentioning that nearly the same view on the age of the rose-like calcite mineralization (latest Permian) was expressed by Wierzbowski (1997). However, the occurrence of subordinate rose-like calcite veinlets cutting lowermost Triassic sandstones suggests that the end phase of this mineralization took place in the earliest Triassic. This is evidenced by some findings done in the Chęciny Castle Hill by Głazek and Roniewicz (1976) and by the present authors in Szczukowskie Górki (unpubl. data).

\section{Materials and Methods}

Due to educational values of the rose-like calcite slabs, only micro-sized samples were collected. In all, 55 samples, weighing 100-200 mg each, were taken with an electric drill from different textural features (Figs. 4 and 6a, b). The small holes were covered with thumbtacks and adequately numbered from 1 through 55. The stable $\mathrm{C}$ and $\mathrm{O}$ isotope determinations were performed on a modified spectrometer MI-1305 on $\mathrm{CO}_{2}$ gas at the Mass Spectrometry Laboratory, Institute of Physics, Maria Curie-Skłodowska University, in Lublin. The $\mathrm{CO}_{2}$ was extracted in a vacuum line at $25{ }^{\circ} \mathrm{C}$ by decomposition of the calcite samples with $100 \%$ phosphoric acid (McCree 1950). The results were reported as $\delta^{13} \mathrm{C}$ and $\delta^{18} \mathrm{O}$ values relative to V-PDB (Vienna PeeDee Belemnite) and given in permil (\%o) units. The standard error of the $\delta^{13} \mathrm{C}$ and $\delta^{18} \mathrm{O}$ was $0.07 \%$.

To determine a contribution of marine water or freshwater to rose-like calcite crystallization, Keith and Weber's (1964) index $Z$ was employed (Eq. 1):

$Z=2.048\left(\delta^{13} \mathrm{C}+50\right)+0.498\left(\delta^{18} \mathrm{O}+50\right)$

The values above 120 indicate an influence of marine waters whereas those below 120 point out the meteoric origin of calcite.

Based on the previous studies (Migaszewski et al. 1996, 1998), the paleotemperatures were computed from Eq. (2) given by Epstein et al. (1953) and Arthur et al. (1983):

$T\left({ }^{\circ} \mathrm{C}\right)=16.9-4.2\left(\delta_{\mathrm{c}}-\delta \omega\right)+0.13\left(\delta_{\mathrm{c}}-\delta \omega\right)^{2}$

where $\delta_{c}$ is the value of $\mathrm{CaCO}_{3}$ and $\delta \omega$ is related to $\delta^{18} \mathrm{O}$ of seawater $\left(\delta^{18} \mathrm{O}_{\mathrm{SMOW}}=0 \%\right.$ ). 


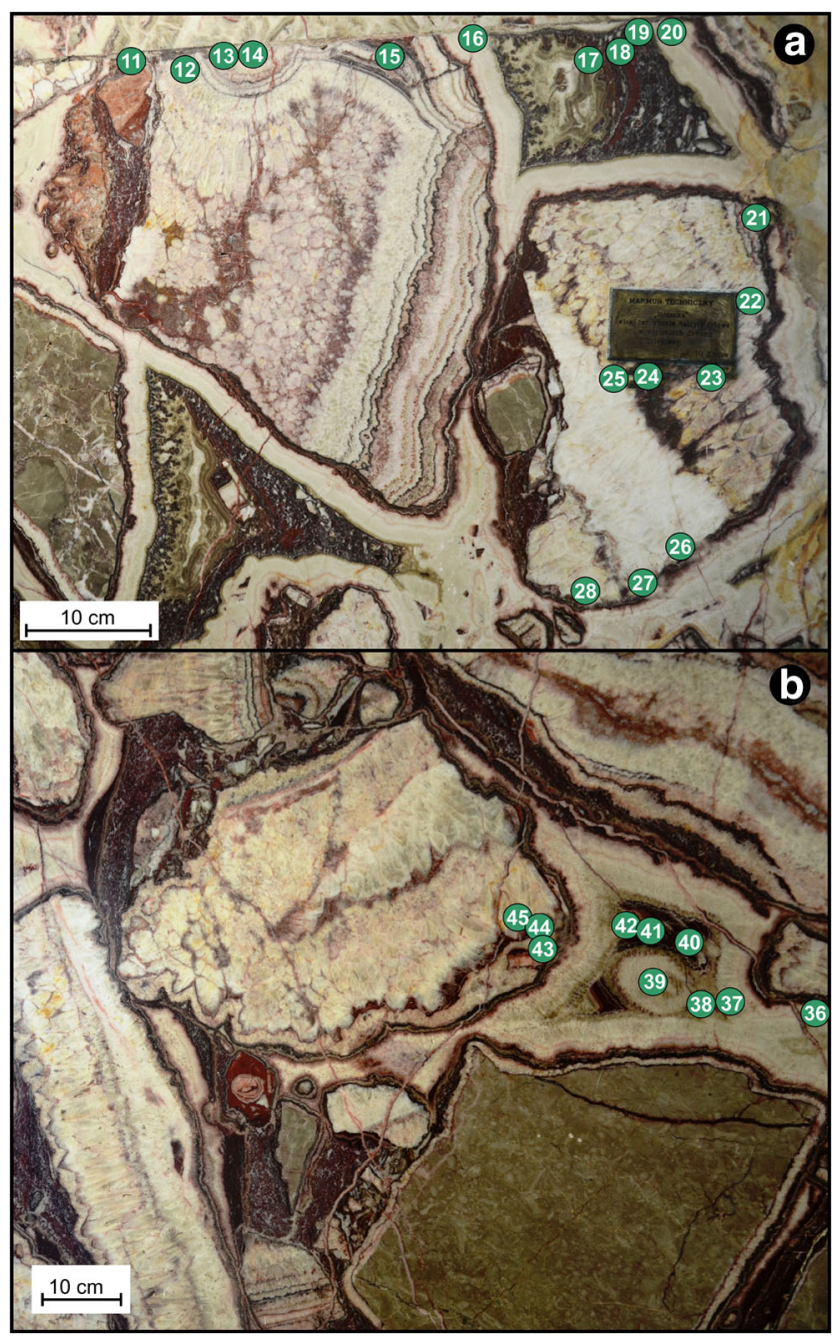

Fig. 6 a, b C-1 and C-2 generations of rose-like calcite on selected polished slabs from the PGI-NRI Museum in Kielce with marked points from which micro-sized samples were collected for stable $\mathrm{C}$ and $\mathrm{O}$ isotope determinations (for the $\delta^{13} \mathrm{C}_{\mathrm{PDB}}$ and $\delta^{18} \mathrm{O}_{\mathrm{PDB}}$ values, see Table 1 ); stalactite embedded in a wavy (crust) calcite vug is depicted in $\mathbf{b}$

\section{Results and Discussion}

The six polished rose-like calcite slabs that face the PGI-NRI Museum pillars in Kielce represent a tectonic breccia composed of calcite and subordinate stromatoporoid limestone pieces. This characteristic feature gives an opportunity to study both temporal and textural relationships between different calcite generations (Fig. 6a, b). The rose-like calcite is commonly highlighted by the presence of dispersed hematite $\left(\alpha-\mathrm{Fe}_{2} \mathrm{O}_{3}\right)$ and colloidal iron hydroxides, and by the lack of sulfide mineral inclusions or quartz and other detritic mineral grains. The pieces consist predominantly of two older calcite generations: (i) Fe- and Mn-rich laminated calcite, fine- to medium-crystalline, red to brown, and (ii) palisade calcite, coarse-crystalline, milky white with subordinate $\mathrm{Fe}$ - and Mn-oxyhydroxide inclusions.
According to Migaszewski et al. $(1996,1998)$, these two generations belong to the older rose-like calcite (phase C-1). At many sites of the Holy Cross Mountains, the palisade calcite fills up inner parts of unbrecciated veins. Its crystals are even several centimeters long, pointing out to good conditions of crystallization in opening fractures. Some of these C-1 calcite pieces comprise subordinate inner ochreous-clayey precipitates (infillings) locally associated with crushed tiny calcite material (Fig. 6a). Both calcite and limestone pieces are cemented by milky-white wavy calcite resembling meteoric flowstones. Vugs within this calcite variety are also infilled with inner precipitates locally with stalactites (Fig. 6b). This wavy calcite corresponds to the earlier-distinguished wavybanded calcite of the younger rose-like calcite (phase C-2) (Migaszewski et al. 1996, 1998). The temporal gap between the two $\mathrm{C}-1$ and $\mathrm{C}-2$ phases is well documented by these textural features.

The provenance and temperatures of crystallization fluids were determined isotopically. The $\delta^{13} \mathrm{C}_{\mathrm{PDB}}$ and $\delta^{18} \mathrm{O}_{\mathrm{PDB}}$ values of rose-like calcite from six museum slabs vary from -3.0 to $1.2 \%$ and from -8.1 to $-1.1 \%$, with a mean of -0.9 $\pm 0.8 \%$ ond $-5.2 \pm 1.8 \%$ (Fig. 7), respectively. Variations in the $\mathrm{C}$ and $\mathrm{O}$ isotope signatures are linked to $\mathrm{CO}_{2}$ solubility that depends on the pressure and temperature of rising and cooling thermal waters (Bottrell et al. 2001). The results of isotope analysis from two selected slabs are in turn presented in Table 1. The $\delta^{13} \mathrm{C}_{\mathrm{PDB}}$ and $\delta^{18} \mathrm{O}_{\mathrm{PDB}}$ values vary from -3.0 to $1.2 \%$ and from -7.9 to $-1.1 \%$, with a mean of $-0.7 \pm$ $0.8 \%$ and $-4.8 \pm 2.0 \%$, respectively. Although one coarsecrystalline calcite (point no. 24 in Table 1) shows the most negative $\mathrm{O}$ isotope signature, there is no correlation between the crystal size and $\delta^{18} \mathrm{O}_{\mathrm{PDB}}$ values. This means that the size of calcite crystals depends mostly on the accessible vug space and not on the crystallization temperature.

Another crucial issue that needs to be solved is a contribution of marine and meteoric fluids to the formation of rose-like calcite, in other words, whether the calcite features described above represent hydrothermal or meteoric paleokarst. Except for fine crystalline, red calcite representing inner precipitate (point 18 in Table 1), all the other calcite samples examined show the index $Z \geq 120$, in the range of 120 to 127. These values are typical for calcite crystallizing from marine fluids (Keith and Weber 1964). For comparison, this index for typical Devonian stromatoporoid limestones varies from 122 to $131(N=20)$. It is interesting to note that the index $Z$ of conglomerate cements of the abandoned "Zygmuntówka" ("Sigismundus") quarry, located approx. $3 \mathrm{~km}$ east of Mt. Zelejowa, ranged from 118 to 123 , reflecting mixed limnic-marine environment of conglomerate deposition (Zbroja et al. 1998).

Based on the assumption that the $\delta^{18} \mathrm{O}_{\text {SMOw }}$ was $0 \%$ (Migaszewski et al. 1995), the "oxygen thermometer" indicates low crystallization temperatures in the range of 21 to 
Fig. 7 The $\delta^{13} \mathrm{C}_{\mathrm{PDB}}$ and $\delta^{18} \mathrm{O}_{\mathrm{PDB}}$ variations in the rose-like calcite samples; note: Sample number 8 (solid triangle and square) is a stromatoporoid limestone

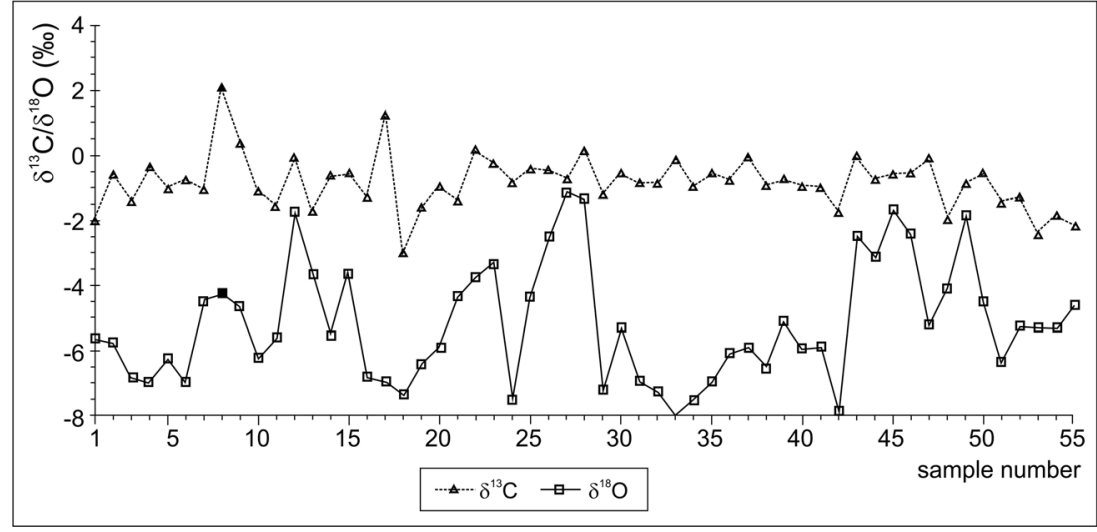

$59^{\circ} \mathrm{C}$. The same values were also derived from homogenization temperature measurements of gaseous-liquid inclusions in rose-like calcite from different sites of the Holy Cross Mts.
(Migaszewski et al. 1996, 1998). It is noteworthy that the stalactite (point no. 39 in Fig. 5b and Table 1) crystallized at a temperature of about $41{ }^{\circ} \mathrm{C}$. The obtained $\delta^{18} \mathrm{O}_{\mathrm{PDB}}$ values

Table 1 The $\delta^{13} \mathrm{C}$ and $\delta^{18} \mathrm{O}$ values with computed crystallization temperatures $(T)$ and indices $Z$ of rose-like calcite slabs in the PGI-NRI museum in Kielce

\begin{tabular}{|c|c|c|c|c|c|}
\hline Sample no. & Sample description & $\delta^{13} \mathrm{C}(\% \circ)$ & $\delta^{18} \mathrm{O}(\% 0)$ & $T\left({ }^{\circ} \mathrm{C}\right)^{*}$ & Index $Z^{* *}$ \\
\hline \multicolumn{6}{|c|}{ Slab no. 1 in Fig. $6 a$} \\
\hline 11 & Calcite fine crystalline, brown & -1.6 & -5.6 & 44 & 121 \\
\hline 12 & Calcite medium crystalline, white & -0.1 & -1.7 & 24 & 126 \\
\hline 13 & Calcite fine crystalline, milky white & -1.8 & -3.6 & 34 & 122 \\
\hline 14 & Calcite fine crystalline, red-brown milky white & -0.6 & -5.5 & 44 & 123 \\
\hline 15 & Calcite fine crystalline, milky white & -0.5 & -3.6 & 34 & 124 \\
\hline 16 & Calcite fine/medium crystalline, milky white & -1.3 & -6.8 & 52 & 121 \\
\hline 17 & Calcite fine crystalline, mottled, white-gray & 1.2 & -6.9 & 53 & 126 \\
\hline 18 & Calcite fine crystalline, red (inner precipitate) & -3.0 & -7.3 & 55 & 118 \\
\hline 19 & Calcite fine crystalline, brown (inner precipitate) & -1.6 & -6.4 & 50 & 121 \\
\hline 20 & Calcite fine/medium crystalline, milky white & -1.0 & -5.9 & 47 & 122 \\
\hline 21 & Calcite fine crystalline, milky white & -1.4 & -4.3 & 38 & 122 \\
\hline 22 & Calcite coarse crystalline, milky white & 0.2 & -3.8 & 35 & 126 \\
\hline 23 & Calcite coarse crystalline, milky white & -0.2 & -3.3 & 32 & 125 \\
\hline 24 & Calcite coarse crystalline, brown & -0.8 & -7.5 & 56 & 122 \\
\hline 25 & Calcite coarse crystalline, white & -0.4 & -4.4 & 38 & 124 \\
\hline 26 & Calcite coarse crystalline, white & -0.4 & -2.5 & 28 & 125 \\
\hline 27 & Calcite coarse crystalline, milky white & -0.7 & -1.1 & 21 & 125 \\
\hline 28 & Calcite coarse crystalline, milky white & 0.1 & -1.4 & 23 & 127 \\
\hline \multicolumn{6}{|c|}{ Slab no. 2 in Fig. $6 b$} \\
\hline 37 & Calcite fine/medium crystalline, milky white & -0.1 & -5.9 & 47 & 124 \\
\hline 38 & Calcite fine crystalline, gray & -0.9 & -6.5 & 50 & 122 \\
\hline 39 & Calcite fine crystalline, milky white (stalactite) & -0.8 & -5.1 & 41 & 123 \\
\hline 40 & Calcite fine crystalline, brown (inner precipitate) & -1.0 & -5.9 & 47 & 122 \\
\hline 41 & Calcite fine crystalline, red-brown (inner precipitate) & -1.0 & -5.9 & 47 & 122 \\
\hline 42 & Calcite fine crystalline, gray & -1.7 & -7.9 & 59 & 120 \\
\hline 43 & Calcite medium crystalline, milky white & 0.0 & -2.5 & 28 & 121 \\
\hline 44 & Calcite fine crystalline, brown & -0.8 & -3.1 & 31 & 125 \\
\hline 45 & Calcite coarse crystalline, milky white & -0.6 & -1.7 & 24 & 125 \\
\hline
\end{tabular}

${ }^{*}$ Based on the assumption that $\delta^{18} \mathrm{O}_{\mathrm{SMOW}}$ at the time of crystallization was 0\%o (Migaszewski et al. 1996, 1998, modified)

*** Keith and Weber's (1964); italics signify the influence of meteoric water during calcite crystallization 
indicate both low and varied crystallization temperatures of rose-like calcite in a terrestrial environment. According to Hölting and Coldewey (2005), a temperature of $20{ }^{\circ} \mathrm{C}$ is regarded as a lower limit of hydrothermal activity. Moreover, the $\delta^{13} \mathrm{C}_{\mathrm{PDB}}$ values averaging $\pm 1 \%$ o show a negligible influence of meteoric water. For comparison, the $\delta^{13} \mathrm{C}_{\mathrm{PDB}}$ values of meteoric flowstones and "calcite groats" from the Chelosiowa Cave (approx. $5.6 \mathrm{~km}$ northeast of Mt. Zelejowa) showed more negative values varying from -10.4 to $-9.3 \%$ and from -9.9 to $-3.7 \%$ o, respectively (Durakiewicz et al. 1995). The presence of dripstones (stalactites) points out to karstification associated with hydrothermal processes (hydrothermal paleokarst). The same phenomena have also been noted at other sites throughout the world (e.g., Dublyansky 1995; Spötl et al. 2009; Dristas et al. 2017). For example, the basal speleothem calcite above the most altered marble of an alpine cave, Entrische Kirche (Austria), exhibited the more negative $\delta^{18} \mathrm{O}_{\mathrm{PDB}}$ values varying from -9.4 to $-8.7 \%$ (Spötl et al. 2009) whereas the calcite of phreatic crusts in large Hungarian caves showed the $\delta^{18} \mathrm{O}_{\mathrm{PDB}}$ values in the range of -14.6 to $-9.5 \%$ (Dublyansky 1995).

Because of its beautiful colors and textures, the rose-like calcite attracts visitors and tourists to the PGI-NRI Museum in Kielce. This decorative mineral is a visiting card of regional geologic and stone mining history and its application to manufacturing of many architectural details in southern Poland, particularly during the late Renaissance period. Both the unique scientific and educational values of this calcite show the significance of geologic museum collections in protecting regional geoheritage (Reis et al. 2014). This is due to the fact that images always predominate over formal and usually misunderstood texts, as emphasized by many authors (Mariotto and Venturini 2017). Moreover, visiting geologic museums is often a starting point to get interested in many aspects of geoheritage, geodiversity, urban geology, or localization of nearby geosites (de Wever et al. 2017; FreireLista and Fort 2018).

\section{Conclusions}

The results derived from textural and stable $\mathrm{C}$ and $\mathrm{O}$ isotope determinations indicate that rose-like calcite formed under terrestrial conditions as a result of overlapping lowtemperature hydrothermal activity with karstification. This is evidenced by $\mathrm{C}$ and $\mathrm{O}$ isotope signatures, index $Z$ values, and occurrences of flowstone and dripstone textures associated with inner ochreous-clayey precipitates. The examined roselike calcite slabs are interesting and untypical specimens that do not occupy much space, but document how combined visual observations and stable $\mathrm{C}$ and $\mathrm{O}$ determinations enable a distinction of vari-temperature mineral generations, detection of their source conditions, and subsequent early-diagenetic alterations. It should be stressed that the $\mathrm{C}$ and $\mathrm{O}$ isotope signatures are the best method to discriminate hydrothermal karst from meteoric karst, which are visually undistinguishable features. Considering this, the use of isotopic analysis is a good example of combining science with education targeting at geoheritage and geodiversity protection. Beautiful colors and textures of the rose-like calcite slabs always attract visitors to the PGI-NRI Museum, enabling them to better understand the significance of this decorative stone in the Renaissance architecture. Needless to say, these specimens will certainly arouse interest in the local geology that may lead to sightseeing in outcrops and historical mining sites.

Acknowledgments We thank Prof. Agnieszka Gałuszka for her assistance in preparing some figures and valuable comments and Mr. Pawel Król for making the photo of Mt. Zelejowa quarry (Fig. 2) available to us.

Open Access This article is distributed under the terms of the Creative Commons Attribution 4.0 International License (http:// creativecommons.org/licenses/by/4.0/), which permits unrestricted use, distribution, and reproduction in any medium, provided you give appropriate credit to the original author(s) and the source, provide a link to the Creative Commons license, and indicate if changes were made.

\section{References}

Arthur MA, Anderson TF, Kaplan IR, Veizer J, Land LS (1983) Stable isotopes in sedimentary geology. SEPM Short Course, No 10

Bottrell SH, Crowley S, Self C (2001) Invasion of a karst aquifer by hydrothermal fluids: evidence from stable isotopic compositions of cave mineralization. Geofluids 1:1103-1121, 103

Czarnocki J (1932) Kielce marbles. Prz Budowl 4:236-237 in Polish

Czarnocki J (1952) Świętokrzyskie marbles. Biul Państw Inst Geol 80: 27-51 (in Polish with English summary)

Czarnocki J (1958) Świętokrzyskie marbles. Pr Inst Geol 21:100-117 (in Polish with English summary)

Dristas JA, Martines JC, van der Kerkhof A, Massonne HJ, Theye T, Frisicale MC, Gregori D (2017) Hydrothermal karst and associated breccias in Neoproterozoic limestone from the Barker-Villa Cacique area (Tandilia belt), Argentina. J S Am Earth Sci 76:182-197

Dublyansky YV (1995) Speleogenetic history of the Hungarian hydrothermal karst. Environ Geol 25(1):24-35

Durakiewicz T, Hałas S, Migaszewski ZM, Urban J (1995) Origin of the "calcite groats" in the Chelosiowa Cave near Kielce (Holy Cross Mts.) inferred from petrographic and isotopic investigations. Geol Quart 39(1):75-94

Epstein S, Buchsbaum R, Lowenstam HA, Urey HC (1953) Revised carbonate-water isotopic temperature scale. Bull Geol Soc Am 64: $1315-1326$

Fijałkowska E, Fijałkowski J (1973) A history of marble exploitation in the Świetokrzyskie Mountains. Zesz Przyr 1:63-141 Świętokrzyskie Museum Kielce (in Polish with English Summary)

Filonowicz P (1961) Geological map of the Świętokrzyski Region without the Quaternary deposits 1:200 000. B Geol Press, Warszawa

Freire-Lista DM, Fort R (2018) Historical city centres and traditional building stones as heritage: Barrio de las Letras, Madrid (Spain). Geoheritage 11:71-85. https://doi.org/10.1007/s12371-018-0314-z

Głazek J, Roniewicz P (1976) On Bundsandstein clastic dykes in the Holy Cross Mts. (Central Poland). Prz Geol 24(8):456-458 in Polish with English Summary 
Hölting B, Coldewey WG (2005) Hydrogeologie. Einführung in die Allgemeine und Angewandte Hydrogeologie, 6th edn. Spektrum, Munich

Keith ML, Weber JN (1964) Carbon and oxygen isotope composition of selected limestones and fossils. Geochim Cosmochim Acta 28: $1787-1816$

Król P (2007) Holy Cross Mountains land in old photographs. National Museum in Kielce (in Polish)

Mariotto FP, Venturini C (2017) Strategies and tools for improving earth science education and popularization in museums. Geoheritage 9: 187-194

McCree JM (1950) On the isotope chemistry of carbonates and a paleotemperature scale. J Chem Phys 18:849-857

Migaszewski ZM, Hałas S, Durakiewicz T (1995) Paleotemperatures of carbonate minerals and barite from the Holy Cross Mts (Central Poland). Prz Geol 43:1011-1016 in Polish with English summary

Migaszewski ZM, Hałas S, Durakiewicz T (1996) The age and origin of the calcite mineralization in the Holy Cross Mts. based on lithologicpetrographic and isotopic evidence. Prz Geol 44:275-281 in Polish with English summary

Migaszewski ZM, Hałas S, Durakiewicz T (1998) Calcite mineralization in the Holy Cross Mts, Poland; the present state of knowledge. Acta Geol Hung 41(1):105-121

Reis J, Póvoas L, Barriga FJAS, Lopes C, Santos FV, Ribeiro B, Cascalho J, Pinto A (2014) Science education in a museum: enhancing earth sciences literacy as a way to enhance public awareness of geological heritage. Geoheritage 6:217-223

Rubinowski Z (1967) Position of the 'rose-like' calcite veins in the Świętokrzyskie Mountains metallogenesis. Kwartalnik Geol 11: 962-963 in Polish
Rubinowski Z (1971) The non-ferrous metal ores of the Świętokrzyskie Mountains and their metallogenic position. Biul Inst Geol 247:3166 in Polish with English summary

Rubinowski Z (1994) 'Rose-like' calcite - vein-breccia variety of the Holy Cross marbles and perspectives of its exploitation renewal. In: Szajn J, Rubinowski Z, Gagol J (eds) Stone materials of the Holy Cross Mountains region - tradition, possibilities, potential of application, Kielce, 17-19 ${ }^{\text {th }}$ Oct, 1994, Świętokrzyskie Voivodship Office, pp 58-60 (in Polish)

Rubinowski Z (1995) Geology, minerals and the 'Karczówka' type lead mining in Kielce area. In: Olszewski JL (ed) Karczówka. Sci Soc Kielce, 93-104 (in Polish)

Spötl C, Dublyansky Y, Meyer M, Mangini A (2009) Identifying lowtemperature hydrothermal karst and palaeowaters using stable isotopes: a case study from an alpine cave, Entrische Kirche, Austria. Int J Earth Sci 98(3):665-676

Wardzyński M (2014) Świętokrzyskie 'Marbles' stonemason center in Chęciny in the 16-19th century. Spotkania z Zabytkami:7-8 (in Polish)

Wever de P, Baudin F, Pereira D, Cornée A, Egoroff G, Page K (2017) The importance of geosites and heritage stones in cities - a review. Geoheritage 9:561-575

Wierzbowski H (1997) Buntsandstein in the karst infillings at Chęciny (Holy Cross Mts, Central Poland) and its significance for regional geological considerations. Prz Geol 45(7):707-710 in Polish with English summary

Zbroja S, Kuleta M, Migaszewski ZM (1998) New data on conglomerates from the "Zygmuntówka" quarry in the Holy Cross Mountains. Biul Państw Inst Geol 379(1):61-79 in Polish with English summary 